\title{
The facets of diachrony ${ }^{\dagger}$
}

\author{
Ioan Milică \\ Faculty of Letters, "Alexandru Ioan Cuza" University, Bd. Carol I 11, 700506 Iași, Romania
}

„Nul ne saurait déterminer la pensée définitive de F. de Saussure”

(Rudolf Engler)

We are spectators of diachrony. This seems to have been the intuition ${ }^{1}$ of the young Ferdinand de Saussure, the linguist considered today the founder of modern linguistics. Just like the young Saussure, we are also spectators of diachrony, but this spectacle focuses on the visions of a man of science resigned that no future seemed possible for his ideas labelled by some contemporaries as outdated, contradictory or ambiguous. According to John E. Joseph, the author of a fascinating monograph dedicated to the life and works of the Swiss scholar, Ferdinand de Saussure reached the end of his life facing the failure of his scientific project: "He managed to persuade the world to think about language in a different way - yet never managed to persuade himself that his thought had reached a form presentable to the public" (Joseph, 2012, p. 651). But, instead of being dissolved into oblivion, the Saussurean scientific view became the cornerstone of structural linguistics.

The costs of this development are difficult, if not impossible to estimate: "Had Saussure ever dreamt of how he would be read and misread, understood and misunderstood, one suspects he would have preferred to remain forgotten" (Joseph, 2012, p. 651). Indeed, among the adepts and admirers of the former professor of Sanskrit and comparative-historical linguistics of Indo-European languages at the University of Geneva, it is rather difficult to discover a linguist without a Saussure "constructed in our own image", as Joseph (2012, p. $\mathrm{x}$ ) puts it in the preface to his outstanding biography. In other words, out of the scientific view of Ferdinand de Saussure grew-just like the branches of a genealogic tree-more or less convergent linguistic orientations, with various degrees of resemblance to the ideas of the founding father: the Geneva school, the French sociological school, the Prague circle, the glossematic circle of Copenhagen, the London school and the systemic-functional linguistics or the psychomechanics of language (Koerner $\&$ Asher, 2008). On more distant orbits, one could mention structural anthropology (Claude LeviStrauss), the semiotic research of some of the members of the Tel Quel group, Lacan's psychoanalysis and Derrida's Deconstructivism. One should also not neglect the attention paid to Saussurean theses by the representatives of Marxist linguistics; it is further worth mentioning the unfair standpoint against the Saussurean semiological project induced in the East after the fall of the Iron Curtain.

\section{Reconstruction}

The source of this complicated interpretative polymorphism manifested throughout a century is to be found in the surprising destiny of the Course in General Linguistics (CGL). This work, posthumously penned by Charles Bally and Albert Sechehaye in collaboration with Albert Riedlinger, was attributed

\footnotetext{
${ }^{\dagger}$ The author would like to thank the anonymous peer reviewers and Prof. Magda Jeanrenaud, PhD, within the Faculty of Letters of "Alexandru Ioan Cuza" University, for their valuable assistance.

*Email address: ioanister@gmail.com.

1 "The idea that with the help of one or two Sanskrit syllables-since that was the main idea of the book and of all contemporary linguistics - one could reconstruct the life of people who had disappeared, inflamed me with an enthusiasm unequalled in its naïveté", a teenaged Saussure confessed (Morpurgo Davies, 2004, p. 14).
} 
to Ferdinand de Saussure in order to mirror the essence of his teachings. For the disciples, the lights of the Saussurean vision ${ }^{2}$ are vivid $^{3}$.

By relating the technique adopted by the editors ${ }^{4}$ to the foreword of the volume Mémoire sur le système primitif des voyelles dans les langues indo-européennes (1879), it may be assumed that the compiling method for the CGL acts as the echo of the Saussurean method ${ }^{5}$ for the reconstruction ${ }^{6}$ of the protoIndo-European vocalism. A posthumous Saussure emended with the exemplary rigour of the rewarding teachings offered by the scholar Ferdinand de Saussure, this must have been the rational, objective and systematic desideratum of the editorial endeavour chosen by the disciples. Applied to the course notes taken by the students who attended the general linguistics courses held between 1907 and 1911 at the University of Geneva, the reconstruction seems to have been applied by the CGL editors in order to compile a work that stirred both enthusiasm and distrust. Published in 1916 (or 1915, considering the date stated by the editors in the preface), the work deemed as the fruit of a difficult restoring act that the author may not have authorized is, according to the most important of Saussure's biographers, "an accident of history" (Joseph, 2012, p. 634).

"Will the critics be able to distinguish between the teacher and his interpreters?" reads the question addressed by the editors to the posterity (CGL, p. xvi). Even a century later, this interrogation is yet to receive a clear and definite answer. In this respect, Antoine Meillet, one of the most important linguists of the early $20^{\text {th }}$ century and a former student of Ferdinand de Saussure, when the latter taught Gothic grammar and high old German at École de Hautes Études in Paris, made a relevant comment. After the publication of the CGL, Meillet published in "Bulletin de la société linguistique de Paris" a rather polemic review, where he singled out the "apocryphal" nature (Bouquet, 2005) of the Course: "Il n'y a pas lieu d'enter ici dans la critique de détail d'un livre qui n'est que l'adaptation d'un enseignement oral fugitif, et où l'on ne sait si les détails qui seraient critiquables viennent de l'auteur ou des éditeurs" (Meillet, 1916, p. 36).

More recently, Simon Bouquet_-another renowned interpreter and editor of Ferdinand de Saussure's writings-highlighted in several works that the subtlety of Saussurean thought and the multifaceted logic of the teachings were not thoroughly understood by the students who took the notes or by the editors who reconstructed the Saussurean theoretical system without attending the lectures themselves. The resulting distortions and "grave confusions" (Rastier, 2012, p. 10) affected the expository accuracy of Ferdinand de Saussure's view precisely in the heart of certain notions of capital importance in the economy of the CGL. For instance, Bouquet argues, "the text of 1916 suggests that, in what regards the arbitrariness of the sign, the lessons refer to a global property of the linguistic sign, while, on the contrary, the Genevan linguist

\footnotetext{
2"Guided by some fundamental and personal principles which are found everywhere in his work-and which form the woof of this fabric which is as solid as it is varied-he tried to penetrate; only where these principles find particularly striking applications or where they apparently conflict with some theory did he try to encompass" (CGL, p. Xv).

3 "F. de Saussure was one of those men who never stand still; his thought evolved in all directions without ever contradicting itself as a result" (CGL, p. xiv).

4"We reached a bolder but also, we think, a more rational solution: to attempt a reconstruction, a synthesis, by using the third course as a starting point and by using all other materials at our disposal, including the personal notes of F. de Saussure, as supplementary sources. The problem of re-creating F. de Saussure's thought was all the more difficult because the re-creaton had to be wholly objective. At each point we had to get to the crux of each particular thought by trying to see its definitive form in the light of the whole system. We had first to weed out variations and irregularities characteristic of oral delivery, then to fit the thought into its natural framework and present each part of it in the order intended by the author even when his intention, not always apparent, had to be surmised" (CGL, p. xiv-xv).

5 "Etudier les formes multiples sous lesquelles se manifeste ce qu'on appelle l'a indo-européen, tel est l'objet immédiat de cet opuscule: le reste des voyelles ne sera pris en considération qu'autant que les phénomènes relatifs à l'a en fourniront l'occasion. Mais si, arrivés au bout du champ ainsi circonscrit, le tableau du vocalisme indo-européen s'est modifié peu à peu sous nos yeux et que nous les voyions se grouper tout entier autour de l'a, prendre vis-à-vis de lui une attitude nouvelle, il est claire qu'en fait c'est le système des voyelles dans son ensemble qui sera entré dans le rayon de notre observation et dont le nom doit être inscrit à la première page" (Saussure, 1879, p. 1).

${ }^{6}$ About the internal reconstruction accomplished by Saussure, see Joseph (2012, p. 233).
} 
focuses strictly on the standpoint of the signifier, in order to state that it has no analogical connection with the signified that it represents-in other words, a classic conventionalist position is uttered" (Bouquet, 1997, p. 284). In fact, Saussure values the notion of ARBITRARY by distinguishing two degrees of arbitrariness: a) the first is an internal arbitrariness of the sign, oriented towards either a conventional signifier in relation to its own signified, or a conventional signified in relation to its own signifier, or the relationship per se between a signifier and a signified and b) the second is a systemic arbitrariness of the sign, referring to the "division' operated by a sign in the substance of which it provides shape" (Bouquet, 1997, p. 288). Furthermore, the systemic arbitrariness of the sign encompasses two distinct aspects: the arbitrariness of the phonological system (highlighting the phonological specificity of languages) and the arbitrariness of the semantic system (emphasizing their semantic specificity). "While the internal arbitrariness of the sign is a pure and limitless arbitrariness per se, the systemic, semantic or phonological arbitrariness of the sign is related to the way a substance can be comprised in a form; it is also an absolute arbitrariness from the perspective of form, but a relative arbitrariness from the perspective of substance, because the relationship between form and substance is a limitation of arbitrariness" (Bouquet, 1997, p. 290).

In the diachrony of the CGL reception, such curving of the lights of Saussurean thought had multiple effects (Koerner, 1971). The most obvious ones were the evolution of structural linguistics schools on distinct conceptual and methodological orbits and the impact of certain key-concepts in the scientific circles more or less close to the matrix of Ferdinand de Saussure's view.

In the first reception phase of the CGL, "the text was not always considered of prime importance within the linguistic community" (Puech, 2004, p. 125). The suspicions surrounding the book were mainly those outlined by Antoine Meillet: the volume reveals a schematized, abstract, and incomplete Saussure, namely a different Saussure than the author of the classic Mémoire.

\section{The interpretative competition}

We know today that the CGL stirred the spirits and fuelled controversies in the interwar period. This is, according to Puech (2004, p. 126), the second reception phase of the book. By the outbreak of World War II, the Course was reedited in 1922 and 1931, and it was included in the riverbed of modern linguistics as a strategic text valued in various scientific circles in order to acquire prestige in relation to the competing trends of the time. The information included in the widely acclaimed edition by Tullio De Mauro (CLG 1998, p. 278-279) shows that, beyond the reviews published in the most important scientific periodicals of the time, the CGL was translated into Japanese (3 editions by 1941), German (1931), and Russian (1933). The tense atmosphere of interpretative clashes was outlined by Percival (1981, p. 43): at the time of publication, the Course was far from being considered a revolutionary work, the main structuralist schools were already founded before the CGL played a decisive influence upon them, and the leaders of these schools did not resonate with the theoretical grounds of the work.

Hence, in Central and Western Europe, the publication of the Course was coldly received by such leading linguists as Antoine Meillet, Hugo Schuchardt ${ }^{7}$, or Otto Jespersen ${ }^{8}$ and it stirred controversies among the adepts of the new structuralist wave (Percival, 1981). The first international congress of linguistics was to bring to light some of the dissensions. The mixture of local colours is outlined by Sextil Pușcariu (1877-1948), the great Romanian linguist who attended the proceedings of the congress organized in 1928 in The Hague. A neogrammarian by formation (Gafton, 2015), Pușcariu pointed out in his

\footnotetext{
${ }^{7}$ The critical examination of certain Saussurean dichotomies-language and speech, synchrony and diachronydetermines the linguist to consider that such distinctions are contradictory or illogical: "there is a false note disseminating in the otherwise so ingenious ensemble of the edifice and weakening it. I would also outline that the distinction between langue and parole lacks logic; we are not talking here about varieties of language, but only about its two parts (formulated as simply as possible: langue is langage without parole), and their relationship is all the closer as it is due to some kind of osmosis" (Schuchardt, in Normand et al., 1978, p. 176-177).

${ }^{8}$ In his review, the Danish linguist notes that the synchronic and diachronic perspectives stand for "what I myself called the statics and dynamics of language" (Jespersen apud Percival, 1981, p. 34).
} 
memoirs the tension between the dominant directions, namely the comparative-historical linguistics and the geolinguistics promoted by Jules Gilliéron, on one hand, and the emergent schools such as the Geneva school, on the other hand:

In general, the final impression is much more discouraging. Everyone is slightly discontent with the way language has been researched thus far. The historical and comparative method has been overused; it is now considered routine and no longer satisfactory, not only because there is not much more to draw from this direction, but mostly because the world has realized it is not the only one to follow and not even the most interesting one. Reconstruction is more or less compromised. An Indo-European ghandi is somewhat ridiculous. Generally speaking, the scholars in Indo-European studies seem to have reached a level where there is nothing more they can do; their research has come to a dead end: Brugmann's name was not uttered even once during the Congress. However, nobody managed to replace the historical-reconstructive and the comparative method with anything else. Attempts have been made by different parties, but they never managed to exceed the borders of the respective country. Different schools were created around powerful personalities; their members are zealous and even fanatic disciples, but they fail to impose. We find ourselves in a complete linguistic regionalism.

(Pușcariu, 1978, p. 806)

This rather pessimistic impressionist picture dominated by the decline of the Neogrammarians is vitalized by the energy of Saussure's disciples. "The second school manifested with certain power and insistence is the Genevan one, represented by Saussure's students, namely Bally and Sechehaye. Their offensive against the historical interests in language research is fierce. Their point of view is certainly too exclusivist. However, it is equally true that the aim of taking into account the static mechanism of language in the study of languages in order to understand its functioning is also legitimate” (Pușcariu, 1978, p. 806).

In the Romanian linguistics of the time, the reception of the CGL was almost instantaneous. In 1922, in the second issue of "Dacoromania", the most important Romanian journal of linguistics published during the interwar period, Vasile Bogrea included a review of the CGL, where he outlined in plain terms the core of the main Saussurean dichotomies:

The first part of the work - there are six of them-accounting for almost a third of the volume is represented by the Introduction, which defines, delimits the field of Linguistics, by distinguishing between a 'science de la parole' and a 'science de la langue', namely a science of speech and a science of language. There are also other lectures, concerning phonetic principles (principes de phonologie). - The Introduction is followed by the general principles that make-up the first part, where a precise distinction is drawn between 'linguistique synchronique' and 'linguistique diachronique', and both of them are examined. The final two chapters concern the linguistic geography and the issue of 'linguistique rétrospective' (reconstruction). A flawless master of setting borders and defining notions, the author rigorously distinguishes between langage, langue, parole, - (human) language, (Romanian) language, speech (word).

(Bogrea, 1922, p. 778)

On the one hand, the review highlights the conceptual and terminological novelty of the CGL, but it also points out the difficulty of properly understanding the key-elements of Saussure's theoretical construction. On the other hand, Saussure's ideas were put to work from the first issue of "Dacoromania" and several papers published between 1921 and 1948 prove that the CGL was quickly adopted among the reference works in linguistics.

In 1925, during the flourishing age of the CGL, Alexandru Philippide-a professor of comparativehistorical linguistics at the University of Iași-launched, in his masterpiece, Originea românilor [The Origins of Romanians], vol. I, a critique of Saussure's view, from the perspective of the concept of LAW 
interpreted within the Neogrammarian framework. By showing that the distinction between "the way of seeing language at a certain point of its existence (linguistique statique, synchronique) and the way of seeing it in its evolution from one moment to another (linguistique évolutive, diachronique)" (Philippide, 2014, p. 376) is legitimate, the author adds that:

What Saussure needs is laws without causes. It is true that in order to formulate laws by induction one does not need to know the causes, in the object per se, but all laws have causes, for nothing exists without a cause (and this is again a postulate of human mind, to which an objective reality certainly corresponds, because nobody really believes in the empty forms of the mind). It would appear that Saussure takes into account certain extraordinary laws, besides nature, that we could not find anywhere. Nevertheless, on the contrary, he considers as term of comparison with the laws of language-whereas he denies their nature of laws-some very real laws, with very apparent causes, namely the laws governing human societies. Saussure, who believes language is a social institution and an arbitrary invention of man (...), is, at the same time, so obsessed with society and with human institutions, that he can only understand the laws instituted by man for governing the society. Any law-in language or in any other field of nature - that does not display human volition is not a law for him (...). When Saussure denies to any law its nature of law because it is not caused by human will and when he calls law only the social law, he restricts the meaning of the word without being necessary. Besides, should there be any distinction between the laws of man for governing the society and the laws of nature exempt from human will, the distinction consists in the fact that the general and imperative character ascribed by Saussure to human laws belongs precisely to natural, and not to human laws. For, only on the realm of human laws are there so many exceptions determined by so many contradictory causes. The human law exists more likely by name, as anyone may violate it without any punishment entailed. It would have been better for Saussure to leave the name of law alone and to have invented a new word for that parody of law fabricated by man to govern society and, unfortunately, to also govern language sometimes, such as when man fabricates all sorts of projects for written languages and literary languages, some more tolerable, while others downright crazy (...)

$$
\text { (Philippide, 2014, I, p. 378) }
$$

The fragment deserves an ampler comment than it would be possible to develop here. Nonetheless, two aspects suggested or formulated by Philippide are worth highlighting:

1. Is Saussurean linguistics a construction built on induction rather than on deduction?

2. How clearly is the concept of LAW presented in the CGL, in comparison to the works of the Neogrammarians and in the view of Ferdinand de Saussure?

Whereas one cannot deny Ferdinand de Saussure's inductive method of teaching (Joseph, 2012, p. 283), which corresponds to the explicitly inductive approach of the Neogrammarians, works such as Mémoire reflect "a mathematical and deductive style of work" (Morpurgo Davies, 2004, p. 28). As far as the second aspect is concerned, the works of Koerner (1971), Bouquet (1997), Joseph (2012) and other linguists reveal that in the Course published by Bally and Sechehaye one may identify enough examples proving that the disciples did not fully grasp the finesse of their master. For instance, Koerner (1971, p. 65-66) notes that, by relating to the students' notebooks, it is possible to identify some of the interpolations made by the editors. Moreover, in the preface to Writings in General Linguistics, a collection of autographed Saussurean notes published in 2002 (Romanian translation 2004, English translation 2006), the editors state that Bally and Sechehaye did not actually edit, but they drafted the book "from beginning to end" (Saussure, 2006, p. xiii). Consequently, Philippide's objection regarding the obsession for "society and human institutions" concerns only tangentially the semiotic insights of Saussure, a scholar for whom "the sociological explanations of linguistic behaviour had only a secondary or tertiary importance", because the Swiss linguist focused on making linguistics a "science in its own right and with a frame of reference 
of its own" (Koerner, 1971, p. 58). Furthermore, if we are to put aside the Course, a work distorted by interpolations and other interventions, the solution is to look elsewhere for the evidence necessary to find out what Saussure believed about the concept of LAw. Fortunately, Writings in General Linguistics include certain fragments allowing us to outline a Saussurean perspective and, even more importantly, the book comprises a draft relevant for the discussion we are interested in at this point:

Since time immemorial language has featured two quite different kinds of things which evoke for us the notion of law. For neither kind of phenomenon is there the least justification for the insistence on this term law; in fact, it would be of great benefit if linguistic inquiry were to be relieved of this word, which would be inept enough if it referred to phonetic laws alone, but its ineptitude is in fact threefold:

a) because it confuses the following two things: the phenomenon by which [...];

b) because if we separate them-progress indeed! - and apply law to relationships [...], that simply expresses an established order, with no imperative force; the meaning of a law being the formulation of an order, just as if I say that the particles in a body are arranged in spirals. That neither implies that these particles must be in spirals, by nature, if a previous force outside our remit had not everywhere arranged them in this way, nor that they must stay in spirals, if a new force unsettles them; but simply that at the present moment, it is possible to observe that they are in spirals, and that such is their order, their present law. Hence law, here means arrangement, order of existing things, order of coexistant things [...];

c) having the force of an imperative, which apparently provides a slightly better justification of the term law.

$$
\text { (Saussure, 2006, p. 166) }
$$

In this draft, the almost mathematical dimension of the concept of LAw becomes apparent. A first element of reference is the law - order - arrangement equivalence, a correlation allowing us to point out the existence of two types of arrangements: the (idio)synchronic law and the diachronic law. As shown by Saussure, law stands for the order of things, from arrangements between coexisting things to arrangements determined between existing facts (in time). Whereas (idio)synchronic law concerns the order of coexisting things (the state), mainly the relations determined between contemporary terms, diachronic law represents an arrangement of successive terms (the event), such as the phonetic change (phonetic $\operatorname{law}^{9}$ ) or the analogical change (morphological innovation). In line with the Neogrammarian precepts, the phonetic change is a purely mechanical operation which involves "no perceptible aim or intention". The phonetic law applies unconsciously upon the physiological and physical side of speech (Saussure, 2006, p. 106). In exchange, the analogical change is an operation "in which it is possible to make out an aim and a meaning". The analogical change is conscious and reflects the psychological and mental side of speech (Saussure, 2006, p. 106).

Hence, there are two types of diachronic arrangement (i.e. of successive terms): mechanical and creative. In Saussure's view, however, law also means principle, namely a fact with general value. In agreement with this meaning, diachronic law also means the condition of language over time. From this perspective, the condition of language over time is guided by two principles that act independently from each other ${ }^{10}$ :

\footnotetext{
${ }^{9}$ The phonetic law applies blindly and with mathematical regularity on all forms of language, "such that one can predict what a Latin word will become in French; what an Indo-European word will be in Greek” (Saussure, 2006, p. 109).

10"These two principles of continuity and mutability of language, far from being contradictory, are in such a close-knit correlation that, as soons as we are tempted to misconceive one, we automatically and unavoidably do unwitting harm to the other" (Saussure, 2006, p. 104).
} 
the principle of absolute continuity ${ }^{11}$ of language in time and the principle of continuous transformation ${ }^{12}$ of language over time. The phonetic change (the mechanical, physiological agent) and the analogical change (the psychological agent) mirror the principle of continuous transformation (Saussure, 2006, p. 111). In the light of these considerations, it is difficult to maintain the objection according to which, in Saussure's theory, the conceptual sphere of law is constrained. Just like Philippide, Saussure refined neogrammarian ideas that he modelled according to his own view.

Returning to the issue of Saussure's reception in Romanian linguistics, it may be noted that several years after the publication of Philippide's book, a student of his-namely the Romance languages specialist Iorgu Iordan-elaborated a consistent dossier regarding the vision of Ferdinand de Saussure, which he included in the volume titled Introducere in studiul limbilor romanice (1932). The work enjoyed positive reviews in the European linguistic circles ${ }^{13}$, but this brief moment of adjustment to European linguistics was perturbed by the outbreak of World War II.

Further East, the reading of the CGL acquired the magnitude of a current of ideas in Russia ${ }^{14}$ (Adamski, 1995, Hutchings, 2004). Moreover, Saussurean teachings collided with Marxist linguistics, which related polemically not only to Saussure's view, but also to the other major bourgeois linguistic orientations, starting with Humboldtian idealism. Over a relative short period, the stake of scientific competition with other directions was "choked" by an exclusively ideological stake: proving the supremacy of Marxism-Leninism (Macrea, 1958; Graur, 1965, p. 214-219).

Towards the end of the 1920s, theoreticians such as Valentin Nikolaevich Vološinov ${ }^{15}$ assumed the task of countering the Western linguistic trends with the project of a philosophy of language to which the Marxist current can also relate. According to this thinker, the epistemological landscape of linguistics was, back then, dominated by two trends: the individualist subjectivism ${ }^{16}$, a Romantic trend with Wilhelm von Humboldt as the towering personality, and the abstract objectivism ${ }^{17}$, a rationalist-Illuminist trend, with

11 "It is worth reflecting a moment on this elementary and essential principle of continuity or necessary uninterruptedness which is the first characteristic or first law of the transmission of human speech, valid whatever various revolutions and upheavals might come to transform conditions... around the language. Whether a people lives peacefully in a secluded valley, whether it be a farming, warring, or nomadic people, which suddenly changes religion, ideas, social situation, and civilization, whether it changes homeland and climate-for it would in that case merely perpetuate by adoption the language of another people - at no time or place has a historical case of the suspension of the continuous line of language known to exist, and one cannot a priori and logically imagine that it might occur in any time or place" (Saussure, 2006, p. 100).

12 "There is endless transformation, but nowhere is there reproduction or production of a new linguistic entity, whose existence is distinct from what preceded it and from what will follow. A language has no mother or daughter, but once it exists a language will fold and unfold endlessly in time; no moment of expiry weighs on its existence, it may not cease to exist, unless an accident, or violence, unless an outside force more powerful than itself sends it into oblivion” (Saussure, 2006, p. 104).

${ }^{13}$ The work was reedited under the title Lingvistica romanică. Evoluție. Curente. Metode $(1962,1970)$ and it was translated into English (An Introduction to Romance linguistics, its schools and scholars, translated by John Orr, 1937, 1970), German (1962), Spanish (1967), Russian (1971), Portuguese (1973), and Italian (1973).

${ }_{14}$ "Young Russian linguists in the years prior to the revolution became acquinted with Saussure not only through his posthumous Cours de linguistique générale [Course in General Linguistics], but also through the interpretation of Saussurian teaching by Sergej Karcevskij, who returned to Russia in 1917 after several years of study in Geneva (...) Russian linguistics in the 1920s clearly reflects the impact of various aspects of Saussure's Course” (Matejka, in Vološinov, 1973, p. 161-162).

${ }^{15}$ Some specialists believe that it may be a pseudonym of Mikhail Bakhtin (Adamski, 1995, p. 243-255).

${ }^{16}$ Vološinov (1973, p. 48) notes that the guidelines of this trend are as follows "1. Language is activity, an unceasing process of creation (energeia) realized in individual speech acts; 2 . The laws of language creativity are the laws of individual psychology; 3. Creativity of language is meaningful creativity, analogous to creative art; 4 . Language as ready-made product (ergon), as a stable system (lexicon, grammar, phonetics), is, so to speak, the inert crust, the hardened lava of language creativity, of which linguistics makes an abstract construct in the interest of the practical teaching of language as a ready-made instrument".

${ }^{17}$ The guiding principles of this trend are: "1. Language is a stable, immutable system of normatively identical linguistic forms which the individual consciousness finds ready-made and which is incontestable for that consciousness. 2. The laws of language are the specifically linguistic laws of connection between linguistic signs within a given, closed linguistic system. These laws are objective with respect to any subjective consciousness. 3. Specifically linguistic connections have nothing in common with ideological values (artistic, cognitive, or other). Language phenomena are not grounded in ideological motives. No connection of a kind natural and comprehensible to the consciousness or of an artistic kind obtains between the word and 
Ferdinand de Saussure as the leading representative.

The main objection brought to the Saussurean project refers to the exclusion of speech from the object of study of linguistics; this is, according to Vološinov, the main false premise (pseudos proton) in the view of the Swiss linguist, who would have "faithfully" followed "the spirit of Cartesian dualism" (Vološinov, 1973, p. 163). One might say that Saussure created a linguistics that excludes the linguistic act but, as shown by Joseph (2012, p. 506), the Genevan scholar did not attempt to separate langue from parole in his lessons ${ }^{18}$, but he insisted upon their interdependence. Moreover, langue is considered a collective treasury of socially used signs, while parole is viewed as "the act of an individual realizing his faculty [langage] by means of the social convention that is the language [langue]" (Joseph, 2012, p. 534). Moreover, Ferdinand de Saussure did not deny the primacy of speech (the praxeological nature of language, Bronckart et al., 2010, p. 340-342), a fact proven by his autographic notes, but he tried to distinguish as clearly as possible between effective and potential speech. He discussed this aspect in his notes (Saussure, 2006) and he outlined from a semiotic perspective the guidelines of two linguistic research fields: the linguistics of language and the linguistics of speech.

By undermining the interdependence between language and speech one also alters the distinction between synchrony and diachrony. Vološinov expresses his belief that Saussure's dichotomy suppresses the possibility "of tying together the existence of language in its abstract, synchronic dimension with the evolution of language. Language exists for the consciousness of the speaker as a system of normatively identical forms, but only for the historian as a process of generation. This excludes any possibility for the speaker's consciousness to be actively in touch with the process of historical evolution. This dialectical coupling of necessity with freedom and with, so to speak, linguistic responsibility is, of course, utterly impossible on these grounds" (Vološinov, 1973, p. 81).

Safer than such an interpretation is the statement that Ferdinand de Saussure did not intend to turn diachronic linguistics into an annex of synchronic linguistics. On the contrary, "he considered historical linguistics to be in need of a fundamental reformation, and made this his life's work, though never with the intention of seeing diachronic enquiry sidelined" (Joseph, 2012, p. 634-635). The interdependence ${ }^{19}$ of the synchronic perspective in relation to the diachronic one (Koerner, 1971, p. 291) is highlighted by John E. Joseph: "To know whether the diachronic law is really a law', we need to observe it at work synchronically, here and now. To know that an element is really part of the speakers' linguistic consciousness and not an abstract figment of the grammarian's analysis, we need to observe it at work diachronically specifically in analogy, since purely phonological evolution does not involve the linguistic consciousness at all" (Joseph, 2012, p. 512).

More broadly speaking, considering the increasing suppression of the international circuit of scientific ideas, the attacks of certain adepts of Stalinist-oriented Marxist linguistics against Saussure's linguistics showed an obvious misconception of the viewpoint opened by Saussure's thought. For instance, Saussure was criticized for having developed "a theory with many merits, but also with grave errors" (Graur, 1965, p. 21) and for having separated language from speech unjustly because he failed to understand "the dialectic unity between language and speech" (Graur, 1965, p. 26). Saussure was also criticized for having created an inadequate semiology for the arbitrariness of the linguistic sign (Graur, 1965, p. 47) or for

its meaning. 4. Individual acts of speaking are, from the viewpoint of language, merely fortuitous refractions and variations or plain and simple distortions of normatively identical forms; but precisely these acts of individual discourse explain the historical changeability of linguistic forms, a changeability that in itself, from the standpoint of the language system, is irrational and senseless. There is no connection, no sharing of motives, between the system of language and its history. They are alien to one another" (Vološinov, 1973, p. 57).

${ }^{18}$ For further details, see Gordon (2004, p. 76-87).

19 “Chez Saussure comparatiste, la dimension synchronique est donc indéniablement présente, et prégnante. La vraie manière de poser la question n'est pourtant pas de constater simplement que l'état et l'évolution de la langue sont distincts en fait (Hermann Paul faisait la même constatation, mais dans une tout autre perspective, comme on l'a vu), elle est de déterminer comment synchronie et diachronie s'articulent entre elles méthodologiquement et théoriquement” (Amacker, 2001, p. 1738). 
having promoted an "idealistic reactionary view"20 (Graur, 1965, p. 95). Beyond the Iron Curtain, in some countries of Eastern Europe, Saussure's linguistic architecture was mutilated by dogmatization, censorship and distortion, and this chapter of the CGL reception could serve as the topic of an extended research on the distortion of great linguistic ideas.

\section{After the war}

Wars change the face of the world. The venerable comparative-historical linguistics of early $19^{\text {th }}$ century flourished during the period following the Napoleonic Wars. The golden age of Neogrammarians' activity is part of a larger series of social and cultural transformations occurring after the Franco-Prussian War. The CGL was published during World War I, while the rise of structuralism as one of the dominant scientific paradigms in the second half of the $20^{\text {th }}$ century is one of the outcomes of World War II. Each new order brought new ideas or remodelled the old ones. In the 1950s, Paris was a fertile field for the seeds of Saussure's theoretical architecture, which became "the common property of linguists, sociologists, anthropologists and philosophers" (Puech, 2004, p. 126). In 1941, the first issue of the prestigious "Cahiers Ferdinand de Saussure", the journal of the Geneva Society of Linguistics, was published and up to now it has welcomed the works of some of the most important linguists in the world. Saussure's name became a name of reference ${ }^{21}$, and his ideas reached the New World (Koerner, 2002, p. 63-73 and passim) due to the activity of the Linguistic Circle of New York (Joseph, 2002, p. 159-163), whose members contributed to the legitimization of structuralism as the framework of a pilot-science: General Linguistics.

One emblematic study for this reception phase was published by the anthropologist Claude LéviStrauss in the first issue of the journal Word (1945) - the publication of the circle that later became the International Linguistic Association. In this manifesto, Lévi-Strauss (1963, p. 33) ascribes a central status to linguistics: "Structural linguistics will certainly play the same renovating role with respect to the social sciences that nuclear physics, for example, has played for the physical sciences". Even if things did not turn out to be quite like this, it is nonetheless true that "notions such as synchrony/diachrony and language system/speech (langue/parole) become the focus of general debates about the shape and status of semiology" (Puech, 2004, p. 127). Moreover, in the eyes of the cultural elite, the name of Ferdinand de Saussure settled as one of the umbrella-names associated with innovation ${ }^{22}$ in humanities. In this third phase, the reception of the CGL surpassed the frame of linguistics and favoured the constitution of a spectrum of approaches, from literary and semiotic critique to cultural history and psychoanalysis; the text drafted by Bally and Sechehaye was considered a work meant to inspire, a "structuralist bible" (Matthews, 2003, p. 142). The Swedish linguist Bertil Malmberg pointed out the ground for this transformation: "Language is a part of culture, while its history is a part of cultural history. It is thus natural for linguistics to acquire-just like the other sciences, art and literature-features characteristic to the periods it crosses (classicism, romanticism, positivism, etc). Just like the school of neogrammarians shared, at the time, the ideology of natural sciences, Saussure's ideas are akin to the trends in contemporary sciences" (Malmberg, 1966, p. 79).

20 "The argument brought by Ferdinand de Saussure was accepted by many Western linguists, because it serves the idealistic views: differences are established by our mind, and positive terms, of a material nature, (sound is the motion of air layers, thus a matter) are eliminated from the discussion. Hence, it reinforces the idea that there is no matter, that the entire world is a figment of our senses" (Graur, 1965, p. 95).

${ }^{21}$ In the French culture of the 1960-1970, the Course... is omnipresent in humanities. Saussure becomes a symbol of modernism, of interdisciplinarity and of speculative spirit (Léon, 2013).

${ }^{22}$ Post 1950, in Eastern Europe, namely in countries such as Romania or Bulgaria (Boyadjiev, 1999), the scientific framework of Ferdinand de Saussure was (re)introduced in university manuals and treatises with a double value: dogmatic (Saussurean linguistics as bourgeois linguistics, cf. Graur, 1965, passim) and scientific (Saussure's linguistics as a founding enterprise, Graur \& Wald, 1977, p. 166-179). 


\section{Internal reconstruction}

While Saussure's theoretical architecture was expanding to other horizons than the tenets of linguistics, the process of philological editing for the CGL began. From 1967, the widely acclaimed edition of the Italian linguist Tullio de Mauro enjoyed a circulation similar to the Bally-Sechehaye edition and it was translated into Korean, Arabic, Croatian, French, Japanese, Hungarian, and Romanian. The text established by Tullio de Mauro was published by Charles Bally and Albert Sechehaye starting with the second edition (1922). It may be stated that the 1950s (Rastier, 2012, p. 7) brought the fourth reception phase of the CGL (Puech, 2004, p. 127), marked by the effort of distinguishing Ferdinand de Saussure's true conception from the interpretations of his disciples. The basic historical facts are well known. In 1957, the Swiss linguist Robert Godel published his doctoral thesis on the manuscript sources of the CGL but, "[i]n spite of its rigorous scholarship, Godel's volume is not easy to peruse. The mixture, in most paragraphs, of summaries, paraphrases, and quotations from Saussure's originals and the students' notebooks makes it difficult to use this thesis as a convenient reference work" (Bouissac, 2010, p. 124).

A decade later, the critical edition of the Swiss linguist Rudolf Engler (vol. I, 1968, and vol. II, 1974) was elaborated not as an antithesis, but as a synthesis of the CGL and of its sources. The synoptic arrangement of the text on six columns denotes the effort of separating clearly the sources of the CGL. Engler (Saussure, 1968, p. x) notes that this technique allows the reader to perceive the discordances and concordances between the students' notes and the text published by Bally and Sechehaye in collaboration with Riedlinger. The first column of the Engler edition features the text of the CGL; columns 2 to 5 reveal the notebooks of the students who attended the three General Linguistics courses taught by Ferdinand de Saussure at the University of Geneva between 1907 and 1911 (Albert Riedlinger, Louis Caille, Léopold Gautier, François Bouchardy, Émile Constantin, George Dégallier, Mrs. A. Sechehaye and Francis Joseph). Finally, the sixth column contains the personal notes of Ferdinand de Saussure. This major editorial achievement is mainly valued within the circles of linguists.

The 1996 discovery of certain Saussurean manuscripts favoured the publication of Writings in General Linguistics (2002, Romanian translation 2004, English edition 2006), a work originally edited by Simon Bouquet, RudolfEngler and Antoinette Weil. Despite these philological successes, the image of Ferdinand de Saussure's theory has not changed significantly (Rastier, 2012, p. 7); the dominant perception is still the one provided by the CGL. Additionally, it may be said that some translations of the CGL deepened the conceptual and terminological distortions of the book, because some translators adopted inaccurate and inexact solutions that altered the text, thus turning it into an impenetrable discourse that the reader ascribes to the author (Jeanrenaud, 2014, p. 167). The amplitude of such distortions is also highlighted by Bouissac (2010, p. 122), who believes that the alteration of Saussure's metalanguage creates confusions that do not allow the reader to access the essence of the Swiss linguist's ideas. A thorough research devoted to the translations of the CGL would probably highlight the magnitude of conceptual and terminological opacity undergone by Saussure's theoretical framework.

In the past two decades, the image of Saussure's ideas gained a fresh momentum: thematic issues of highly regarded scientific journals were published ("Langages", issue 185/2012), guides and collective works were edited (Arrivé \& Normand, 1995; Sanders, 2004; Bouissac, 2010; Bronckart et al., 2010) and a monumental biography of the life and works of Ferdinand de Saussure caught the public's eye (Joseph, 2012). Linguistic works have featured increasingly used formulas such as neo-Saussurean linguistics or neo-Saussurean epistemology. One century after the publication of the CGL, the original and iconoclastic view of Ferdinand de Saussure (Joseph, 2012, p. 513) is still able to nourish linguistic research. Do the diachronic facets of the CGL reception make up a system of oppositions in which "tout se tient ${ }^{23}$ "?

\footnotetext{
${ }^{23}$ For a history of this formula, see Koerner (1997).
} 


\section{Bibliography}

Adamski, D. (1995). Saussure et les linguistes russes, in Arrivé \& Normand (1995), p. 243-255, [online].

Amacker, R. (2001). La dimension synchronique dans la théorie linguistique de Saussure, in Auroux, S., Koerner, E.F.K., Niederehe, H.-J. \& Versteegh, K. (eds), History of the Language Sciences / Geschichte der Sprachwissenschaften / Histoire des sciences du langage. An international Handbook on the Evolution of the Study of Language from the Beginnings to the Present / Ein internationales Hanbuch zur Entwicklung der Sprachforschung von den Anfägen bis zur Gegenwart / Manuel international sur l'évolution de l'etude du langage des origines à nos jours, vol. 2, Walter de Gruyter, Berlin - New York, p. 1735-1746.

Arrivé, M. \& Normand, C. (eds) (1995). Saussure aujourd'hui, special issue of the journal "LINX", [online].

Bogrea, V. (1922). Ferdinand de Saussure, Cours de linguistique générale, publié par Ch. Bally et Albert Sechehaye, avec la collaboration de Albert Riedlinger, Lausanne și Paris, 1916, 336 p. in - 8', in "Dacoromania", year II, p. 777-778.

Bouissac, P. (2010). Saussure. A guide for the perplexed, Continuum, London - New York.

Bouquet, S. (1997). Introduction à la lecture de Saussure, Éditions Payot \& Rivages, Paris.

Bouquet, S. (2005). Apres un siècle, les manuscrits de Saussure reviennent bouleverser la linguistique, in “Texto!", [online].

Boyadjiev, J. (1999). Ferdinand de Saussure en Bulgarie, in Embleton, S., Joseph, J.E. \& Niederehe, H.-J. (eds), The Emergence of the Modern Language Sciences. Studies on the transition from historical-comparative to structural linguistics in honour of E.F.K. Koerner, vol. 1: Historiographical perspectives, John Benjamins, Amsterdam, CrossRef.

Bronckart, J.P., Bulea, E. \& Bota, C. (2010). Le projet de Ferdinand de Saussure, Librairie Droz, Geneva - Paris.

CGL $=$ Saussure, F. de (1968). Cours de linguistique générale, critical edition by Rudolf Engler, tome I, Otto Harrassowitz, Wiesbaden.

CLG 1998 = Saussure, F. de (1998). Curs de lingvistică generală, Romanian edition by Irina Izverna Tarabac, critical edition by Tullio de Mauro, Editura Polirom, Iaşi.

Gafton, Al. (2015). Sextil Puşcariu - neogramaticul, in "Caietele Sextil Pușcariu”, vol. II, p. 166-173.

Gordon, T.W. (2004). Langue and parole, in Sanders (2004), p. 76-87, CrossRef.

Graur, Al. (coord.) (1965). Introducere in lingvistică, second edition, Editura Științifică, București.

Graur, Al. \& Wald, L. (1977). Scurtă istorie a lingvisticii, third edition, Editura Didactică şi Pedagogică, București.

Hutchings, St.C. (2004). The Russian critique of Saussure, in Sanders (2004), p. 139-156, CrossRef.

Iordan, I. (1962). Lingvistica romanică. Evoluție, curente, metode, Editura Academiei R.P.R., București, p. 285-303.

Jeanrenaud, M. (2014). La traduction des concepts dans le discours des sciences humaines, în Schippel, L., Jeanrenaud, M. \& Richter, J. (eds), „Traducerile au cuget să îmblinzzească obiceiurile...” / Rumänische Übersetzungsgeschichte - Prozesse, Produkte, Akteure, Frank \& Timme, Editura Universității „Alexandru Ioan Cuza”, Iași, p. 153-178.

Joseph, J.E. (2002). From Whitney to Chomsky. Essays in the history of American linguistics, John Benjamins Publishing Company, Amsterdam - Philadelphia, CrossRef.

Joseph, J.E. (2012). Saussure, Oxford University Press.

Koerner, E.F.K. (1971). Ferdinand de Saussure. Origin and Development of his Linguistic Theory in Western Studies of Language. A Critical Evaluation of the Evolution of Saussurean Principles and Their Relevance to Contemporary Linguistic Theories, Simon Fraser University, December 1971, doctoral thesis, [online].

Koerner, E.F.K. (1997). Notes on the History of the Concept of Language as a System 'où tout se tient', in "Linguistica Atlantica", issues 18-19, p. 1-20, [online].

Koerner, E.F.K. (2002). Toward a History of American Linguistics, Routledge, Taylor \& Francis Group, London - New York.

Koerner, E.F.K. \& Asher, R.E. (eds) (2008). Concise History of the Language Sciences. From the Summerians to the Cognitivists, Pergamon, Cambridge.

Léon, J. (2013). Historiographie du structuralisme généralisé. Etude comparative, in “Dossiers d'HEL”, SHELS, 2013, Les structuralisms linguistiques: problèmes d'historiographie comparée, 3, p. 1-23, [online].

Lévi-Strauss, Cl. (1963). Structural Analysis in Linguistics and in Anthropology, in Structural Anthropology, translated from the French by Claire Jacobson and Brooke Grundfest Schoepf, Basic Books, New York, p. 41-54.

Macrea, D. (1958). Aplicarea marxism-leninismului in lingvistica romînească, in "Studia Universitatum Victor Babeș et Bolyai", tomus III, issue 6, series IV, Fasciculus 1, Philologia, p. 9-25.

Malmberg, B. (1966). Les nouvelles tendances de la linguistique, translated from Swedish by Jacques Gengoux, Presses Universitaires de France, Paris.

Matthews, P. (2003). A Short History of Structural Linguistics, Cambridge University Press.

Meillet, A. (1916). Ferdinand de Saussure - Cours de linguistique générale, publié par Ch. Bally et Albert Sechehaye, avec la collaboration de Albert Riedlinger, Lausanne și Paris (Payot), 1916, in - 8, 337 p., in "Bulletin de la société linguistique de Paris", vol. 20, 1916, p. 32-36.

Morpurgo Davies, A. (2004). Saussure and Indo-European Linguistics, in Sanders (2004), p. 9-29, CrossRef.

Normand, C. et al. (1978). Avant Saussure. Choix de textes (1875-1924), Editions Complexe, Bruxelles.

Percival, K.W. (1981). The Saussurean paradigm: Fact offantasy?, in "Semiotica”, vol. 36, issues 1-2, p. 33-49, CrossRef. 
Philippide, A. (2014). Originea românilor, edited by Roxana Vieru, Editura Universității „Alexandru Ioan Cuza”, Iași, p. 376378.

Puech, Chr. (2004). Saussure and structuralist linguistics in Europe, in Sanders (2004), p. 124-138, CrossRef.

Pușcariu, S. (1978). Memorii, Editura Minerva, București.

Rastier, Fr. (2012). Lire les textes de Saussure, in Depecker, L. (ed.) (2012), L'apport des manuscrits de Ferdinand de Saussure, „Langages”, issue 185, 1/2012, p. 7-20, CrossRef.

Sanders, C. (ed.) (2004). The Cambridge Companion to Saussure, Cambridge University Press, CrossRef.

Saussure, F. de (1968). Cours de linguistique générale, critical edition by Rudolf Engler, tome I, Otto Harrassowitz, Wiesbaden. Saussure, F. de (1879). Mémoire sur le système primitif des voyelles dans les langues indo-européennes, B.G. Teubner, Leipzig.

Saussure, F. de (2006). Writings in General Linguistics, edited by Simon Bouquet, Rudolf Engler, Carol Sanders and Matthew Pires, Oxford University Press.

Vološinov, V.N. (1973). Marxism and the Philosophy of Language, English edition by Matejka, L. and Titunik, I.R., Seminar Press, New York - London. 